\title{
Citric Acid Monohydrate
}

National Cancer Institute

\section{Source}

National Cancer Institute. Citric Acid Monohydrate. NCI Thesaurus. Code C47452.

A tricarboxylic acid found in citrus fruits. Citric acid is used as an excipient in

pharmaceutical preparations due to its antioxidant properties. It maintains stability of active ing redients and is used as a preservative. It is also used as an acidulant to control $\mathrm{pH}$ and acts as an anticoagulant by chelating calcium in blood. 